\title{
Strategic Policies in Expanding Frontiers of Food Security among Cassava-based Farmers in Cross River State, Nigeria
}

\author{
Emmanuel Edet Agbachom ${ }^{1}$, Amalu Melvin ${ }^{1}$, Uzoikwe Amata ${ }^{1}$, Otu Ettah ${ }^{1}$ \\ and Godwin Michael Ubi ${ }^{2^{\star}}$
}

${ }^{1}$ Department of Agricultural Economics and Extension, Faculty of Agriculture, Forestry and Wildlife Management, University of Calabar, Calabar, Nigeria.

${ }^{2}$ Department of Genetics and Biotechnology, Faculty of Biological Sciences, University of Calabar,

Calabar, Nigeria.

Authors' contributions

This work was carried out in collaboration among all authors. Authors EEA, AM, UA, OE designed the study, authors GMU, EEA and OE performed the statistical analysis, authors GMU and AM wrote the protocol, authors GMU and EEA wrote the first draft of the manuscript. Authors GMU and EEA managed the analyses of the study. Author GMU managed the literature searches. All authors read and approved the final manuscript.

Article Information

DOI: 10.9734/ARRB/2019/v33i530133 Editor(s):

(1) Paola Angelini, Department of Applied Biology, University of Perugia, Perugia, Italy. Reviewers:

(1) Olutosin A. Otekunrin, Federal University of Agriculture, Nigeria. (2) Sergei N. Polbitsyn, Ural Federal University, Russia.

(3) Subrata Kumar Mandal, CSIR-Central Mechanical Engineering Research Institute, India. Complete Peer review History: https://sdiarticle4.com/review-history/52780

Original Research Article

Received 02 September 2019

Accepted 11 November 2019

Published 15 November 2019

\section{ABSTRACT}

The research was carried out to identify the possible constraints and development of strategic policies in expanding and improving cassava production and processing amongst cassava value chain actors in Cross River State, Nigeria. Data generated from the research the 150 cassava producers and processors (cassava value chain actors) through the use of well- define structured interview schedule was collated. The Multistage sampling procedure was adopted in selection of farmer respondents. The multivariate analytical technique was used in analyzing generated data employing the statistical application software of Genstat version 12. The eigen value, percentage variations and loading values contributing to low cassava output were used in achieving the 
objectives. The results showed that the major constraints to cassava production and processing were agronomic, technical/institutional and financial constraints. The major policy strategies should include a global, national, regional and community strategies all geared towards the evolution of industry analysis for improving cassava productivity in the study area through the development of the traditional farming systems, making good planting material accessible to farmers and on time and at lowest possible prices; the provision of credit facilities to the resource poor cassava -based farmers in the area with no collateral; the establishment of cassava product based cottage industries in the area for cassava value chain development; provision of adequate cassava processing equipment and the formation of cassava farmers' multipurpose cooperative societies to enhance farmers' access to benefit from world bank assisted programmes; have free access to basic information and production facilities. The study, therefore, recommended that cassava product based cottage industries be established in the study area in order to encourage both producers and processors in the value addition chain. This will also provide employment and likewise encourage the restive youths in the region to venture into agriculture as a business for economic returns, growth and development of the area. The identified constraints with the higher loading values for each of the principal multivariate should be strengthened using appropriate development strategies/policies to ensure food security and increased farm income for cassava - based farmers in the region.

Keywords: Value chain development; multivariate analysis; Manihot esculentus; global; national and regional strategies; adequate extension delivery system.

\section{INTRODUCTION}

Cassava has become a very popular crop and is fast replacing yam and other traditional staples of the area, gaining ground increasingly as an insurance crop against hunger [1]. The concepts of food security and food sustainability are two main paradigms in the food system discourse however, they are often addressed separately in the scientific literature [2]. The twenty first century ushered in the most important aspect of agricultural improvements since human existence. Research and technology based agriculture had evolved rapid changes on the farming system and triggered the changes from traditional agriculture to a more reliable and productive modern agriculture [3]. Linkages between food sustainability and food and nutrition security intersect at global, national, local, and household levels. Different strategies can be pursued to foster sustainability transitions in food systems: efficiency increase (e.g., sustainable intensification), demand restraint (e.g., sustainable diets), and food systems transformation (e.g., alternative food systems) [2]. As agricultural productivity increases and farmers income improves, they begin to realize the need to remain in certain crops or products. This scenario has often resulted in the increase and development of agriculture based private entrepreneurs and the establishment of non-farm private sectors in rural areas. As technology and research based agriculture continues to thrives, individual and entrepreneurial participation in offfarm businesses such as food processing, financial operations including inputs supply and other materials, transportation, marketing and other services also increases. This has brought about sustained economic growth in many countries were this has been practiced, thus leading to overall increased productivity in agriculture. Agriculture shows a high potential as vehicle for industrialization, sustained economic growth and development. Technological changes in agriculture however requires a constant flow of new technologies to farmers and a wide range of options usually brought by a good agricultural extension delivery network $[4,5]$.

Nigeria remains the highest producer of cassava in the world, producing one-third more than Brazil and almost twice the production capacity of Thailand and Indonesia [6,7]. Nigeria at the moment produces about 38 million metric tonnes (MT) annually; a volume expected to double by 2020. Although the world leader in cassava production, Nigeria is not an active participant in cassava trade in the international markets because most of her cassava is targeted at the domestic food market. However, her production methods are primarily subsistence in nature and therefore unable to support industrial level demands [4,8]. Waha, et al. [9] endorsed that the relationship between farming diversity and food security and the diversification potential of African agriculture and its limits on the household and continental scale. The consistent increase in the global population, estimated to reach 9 billion people by 2050 , poses a serious challenge for the achievement of global food security. 
Therefore, the need to feed an increasing world population and to respond adequately to the effects of climate change must be urgently considered [10].

Cassava provides food security as it can be grown on less fertile soils, it is a source of income for farmers and provides food for many household. An investigation was conducted in Ndokwa West Local Government Area of Delta state Nigeria to find out the variable inputs that affects the output of cassava farming households [11]. Manihot esculentus, Cassava is among the world's most important food crops. In Nigeria, cassava remains one of the most important sources of carbohydrate nutrient. It grows to a height range of between 1 and $3 \mathrm{~m}$ depending on the variety and possesses fibrous adventitious roots on each plant which later develops into fleshy root tubers. Cassava leaves are consumed in some communities but the major edible portion is the root tuber, which is a swollen root. Cassava is mostly propagated from stem cuttings. According to FAO [8], cassava ranks very high among staple crops that contains high amount of energy in the form of soluble carbohydrates per unit of size of tuber. Compared to other starchy staples, cassava is very rich in carbohydrate production and supply about $40 \%$ higher than rice and $25 \%$ greater than maize. Hence, cassava abounds as the cheapest source of calories for both human and livestock nutrition. Proximate composition of the cassava root reveals that moisture $(70.10 \%)$, starch $(23.98 \%)$, fiber $(1.99 \%)$, protein $(1.03 \%)$ and other substances including vitamins and minerals $(2.94 \%)$. A recent report on cassava shows that it constitutes about $70 \%$ of the total calories intake of more than half of the population [12].

The cassava crop farming supports the livelihood of up to half a billion farmers and countless processors and traders in the cassava value chain around the globe. It remains the basic staple for hundreds of millions of people in the tropical and subtropical regions of the world, as well as a feedstock and recipe for numerous industrial applications, including food, fuel, feed and starch. Cassava production is synonymous with small holders subsistence agriculture usually carried out by resource poor farm households. This relationship exists because the resource poor farm households are not involved in agricultural policies and decision making and are often left out in the scheme of things that concerns them by the government [13].
For some time now, the production and processing of cassava produce have been faced with a lot of challenges. Consequently, no adequate supply chain structures are put in place to promote the commercialization of cassava products as primary sources of raw materials for agro-allied cottage industries. At the farm gate strata, the production costs for cassava crop are high in Nigeria when compared to other cassava producing countries. Cassava production in Cross River State is not targeted towards commercialization but rather for subsistence where the cassava- based farmers produced and processed cassava for domestic utilization and local markets only. This has triggered the need to expand the frontiers of the local cassava based farmers to increased productivity [14] which has been embraced with a major limitation of rapid postharvest deterioration of its tuber roots which usually prevents their storage in the fresh state for few days [15].

Cassava crop production and processing remains a vital organ of food security in the study area and Nigeria at large, not only because it can be grown on less productive land or been a hardy crop, but because it is a source of income for farmers and other value chain actors and generally a cheap source of low cost food. This suggest that the development of cassava based cottage industries and market for cassava products can contribute meaningfully towards alleviating rural poverty in the study area especially for the resource-poor farm households and subsequently increase household income and food security [16].

The current pattern of cassava production in Nigeria has mounted pressure on production of cassava. The Nigerian Government recently constituted a proactive governmental initiative on cassava production and export which was aimed at raising the production level of cassava to 150 million metric tonnes by the end of the decade [17]. It was also aimed at substituting wheat flour with cassava flour in bread making. The programme is also expected to assist the country realize a projected foreign income reserve of US $\$ 5.0$ billion per annum from the export of 37.6 million tonnes of processed dry cassava products such as starch, cassava chips, ethanol, glue and other product derivatives. Besides local demand, there is also a high demand for cassava based products in foreign countries such as China. This also has triggered the need to expand the frontiers of local production and supply so as to 
be able to satisfy foreign market demand for cassava based products [18].

Some of the achievements recorded by the proactive government initiative on cassava production and export included the organization of training workshop at the national centre for agricultural mechanization (NCAM) llorin, for the development of equipment for the processing of various cassava products which are targeted for the export market in synergy with the International Institute for Tropical Agriculture (IITA) [19]. It also secured the production and distribution of 576,000 bundles of improved cassava cutting of improved varieties like TMS 1368, TMS 1371, TMS 1412 (all carotene based), and NGR 8081, TMS 30525, TMS 30542 etc by the State Agriculture Development Projects (ADPs) to cassava farmers. This was also achieved in the Cross River State Agricultural Development programe (CRADP). The initiative also expanded the production/procurement of planting materials, such as breeds, foundation and certified stocks by the Root and Tuber Expansion Programme Management Unit (RTEPMU), NRCRI, Umudike and JITA; and conjunction with rural communities to establish cottage cassava processing centres in each local government area of the cassava producing states for subsequent replication and adoption [20].

However, despite the success stories made by different groups and individuals at the federal, state and local government stratas to increase and improve the cassava value chain in terms of production, processing, transportation, marketing, distribution and utilization in Nigeria, the crop is yet to realize it full productive potentials in Cross River State and thus the heightened need to align strategic policy proposal that will increase cassava crop yields and which will translates to greater incomes of the rural cassava farmers [21]. It therefore becomes important to evaluate and rationalize strategic policies that could expand the production of cassava and also identify factors constraining cassava production and processing in the selected region of Nigeria using Cross River State as a case study.

\section{METHODOLOGY}

\subsection{The Study Area}

The research was conducted in the cassava producing communities in the three senatorial districts of Cross River State, South-South region of Nigeria. Cross River State lies in the mangrove and deciduous rain forest belt of Nigeria with some of the biggest forest reserve and biodiversity hotspots in Africa. The state lies between latitude $04^{\circ} \mathrm{N}$ and longitude $09^{\circ} \mathrm{E}$. The mean diurnal temperature range between $25^{\circ} \mathrm{C}$ and $29^{\circ} \mathrm{C}$ with a promising climate and seasons for the growing of cassava in the area, which include rainy season (April-October) with a dry spell in August and dry season (NovemberMarch). The state has an estimated population of about 1, 694,121 persons (National Population Commission, 2006).

\subsection{Sampling Techniques}

The Multistage random sampling technique was employed in the selection of cassava based farmer respondents for the study in the area. In the first instance, three (3) senatorial district were considered and there included the Southern, Northern and Central senatorial districts. Five (5) local governments were further selected from each senatorial district using simple random sampling technique. In the second instance, two communities out of the list of five communities provided by the agricultural extension agents in the various local governments were randomly selected from each of the 5 LGAs, making a total of 10 communities. In the third instance, it involved the selection of cassava based individual farmer respondents. Ten (10) cassava farmers who were involved in both cassava production and processing were purposely selected and interviewed for the study from each of the ten communities selected. This was because, in the study area, most of the producers also process their tubers to finish products. Thus, a total of 150 cassava producers and processors constituted the population size for the study. Data for the study were collected from the respondents through the use of interview schedule and questionnaire.

\subsection{Data Collection Procedures}

In trying to obtain possible strategies towards improving cassava value chain in the study area, the research approach focuses on the possible introduction, promotion and adoption rate of the global, national, regional and community based strategic development policies for cassava in the area. A 4 point Likert-type scale with three response options (4 Very effective; 3 = Effective; $2=$ Not effective and $1=$ Never implemented) was adopted. The values on the Likert-type scale were summed and the percentage score of each variable as a percentage of the total was 
estimated. The F-ratio or variance ration was also adopted to determine the significance of each adopted strategies to the expansion of cassava productivity in study area. Strategies with significant impact were considered as strategic policies that should use in the development of global model for cassava crop productivity and value chain development.

\subsection{Data Analysis Procedures}

Multivariate analysis procedure adopting the principal component analysis showing corresponding major loading values or major contributory variables was employed in grouping the constraint variables into major constraint (principal loading/limiting values) factors and least contributory variables with negative values. Genstat version 12 software was used to analyze the generated data at 95 percent significance level.

\section{RESULTS}

\subsection{Multivariate Analysis of Perceived Constraints}

The results of multivariate analysis of the perceived constraints/factors militating against cassava value chain development in the study area are presented in Table 1. Three principal production pathways or components of the multivariate constraints were used to explain the negative impact of the perceived constraints on cassava productivity in the area. The major limiting constraints/factors to cassava productivity in the area were obtained in the first principal component contributing about $99.54 \%$ to the poor yield of cassava in the area. The major limiting (loading values) factors in this principal components as presented in Table 1 include poor access roads for the evacuation of cassava produce from the farms $(23.64 \%)$, lack of collateral for loan acquisition by cassava farmers in the area (20.40\%), lack of processing equipment for cassava tubers $(8.02 \%)$, high cost of cassava farm inputs $(10.71 \%)$, absence of mechanized equipment for cassava farming operations $(5.51 \%)$, high interest rate on loans $(4.96 \%)$, lack of technical knowhow on cassava production and processing (4.26\%), lack of credit facilities $(5.001 \%)$ and low genetic make-up of cassava varieties used by farmers in the area (8.14\%) (Table 1).

The second principal component contributed a smaller percentage of only $0.32 \%$ to the total losses experienced by cassava farmers in the study. The loading militating values explaining this barriers in this component include the lack of good planting materials $(6.30 \%)$, lack of collateral by farmers to acquire loans for cassava value chain development $(7.98 \%)$, poor access roads to cassava evacuation (10.09\%), poor agricultural extension delivery system (10.06\%), low market value of cassava products in the area $(9.04 \%)$ and lack of adequate market for cassava products in the area $(9.06 \%)$ (Table 1).

The loading limiting factors or constraints to cassava productivity as explained in the third principal components shows that only $0.14 \%$ of total losses were triggered by limiting factors in this principal production pathway (Table 1). The problem of land tenure system contributed $(5.25 \%)$ to the limiting factors, high interest rate on loan contributed (4.89\%), negative impact on the use of agrochemicals on soil and cassava crops in the area $(6.35 \%)$ and the high cost of inorganic fertilizer (3.077\%) in the area (Table 1).

\subsection{The Policy Strategies in Expanding Frontiers of Cassava Production}

The policy strategies adoption rate for the expansion of the frontiers of cassava value chain in the study area was evaluated and presented in Table 2. The results as presented shows that policy strategies such as the formation of cooperative groups among cassava based farmers in the area $(78.65 \%)$, the provision of equipment for the development of the cassava value chain $(54.24 \%)$, provision of subsidy for inputs to farmers $(60.23 \%)$, provision and availability of planting materials at the right time $(79.45 \%)$, provision of fertilizer at the right time to farmers $(54.42 \%)$, use of improved and disease resistant varieties of cassava as planting materials (89.20\%) and the planting of improved cassava varieties by farmers $(85.93 \%)$ in the study area all showed high mean adoption rate and showed significance impact on cassava based systems and value chain development in the area as shown in Table 2.

However, policy strategies like creation of credit facilities to farmers $(10.32 \%)$, reduction of high interest rate $(12.87 \%)$, creation of markets $(34.12 \%)$, use of recommended agronomic best practices for cassava production (21.15\%), routine weeding of cassava farms $(38.96 \%)$ and regular visits by agricultural extension agents $(17.43 \%)$ showed a low mean percentage adoption rate (Table 2 ) and consequently did not 
Table 1. Multivariate analysis of identified constraints militating against increased cassava productivity in the Niger Delta Region: A case study of Cross River State, Nigeria

\begin{tabular}{|c|c|c|c|c|c|c|}
\hline AXIS & PC1 & & PC2 & & PC3 & \\
\hline Eigen Value & 118.8906 & & 77.39449 & & 59.79062 & \\
\hline Impact \% & 99.54 & & 0.32 & & 0.14 & \\
\hline Cum. Impact \% & 99.54 & & 99.86 & & 100.00 & \\
\hline Constraint & $\begin{array}{l}\text { Axis1 } \\
\text { Coord. }\end{array}$ & $\operatorname{Cos}^{2}$ & $\begin{array}{l}\text { Axis } 2 \\
\text { Coord. }\end{array}$ & $\operatorname{Cos}^{2}$ & $\begin{array}{l}\text { Axis } 3 \\
\text { Coord. }\end{array}$ & $\operatorname{Cos}^{2}$ \\
\hline $\begin{array}{l}\text { Poverty level of } \\
\text { farmers }\end{array}$ & -0.6880 & 0 & 0.2059 & 0 & -0.1975 & 0 \\
\hline $\begin{array}{l}\text { Lack of good planting } \\
\text { materials }\end{array}$ & -1.2120 & 2 & 6.3090 & 42 & 2.0907 & 5 \\
\hline Lack of credit facilities & 5.0021 & 16 & -11.1339 & 80 & -14.006 & 127 \\
\hline Problem of land tenure & 1.3603 & 2 & -4.2386 & 15 & 5.2523 & 22 \\
\hline Lack of tech. knowhow & 4.2605 & 14 & 2.3121 & 4 & -0.5867 & 0 \\
\hline $\begin{array}{l}\text { High cost of farm } \\
\text { inputs }\end{array}$ & 10.7114 & 84 & -4.4590 & 15 & $-1-0614$ & 1 \\
\hline $\begin{array}{l}\text { High interest rate on } \\
\text { loans }\end{array}$ & 4.9680 & 20 & 1.5139 & 2 & 4.8964 & 19 \\
\hline High cost of hired laour & 1.5267 & 2 & 0.6725 & 0 & 1.1691 & 1 \\
\hline $\begin{array}{l}\text { Lack of processing } \\
\text { equipment }\end{array}$ & 8.0241 & 44 & -8.5030 & 50 & 3.7597 & 10 \\
\hline $\begin{array}{l}\text { Absence of } \\
\text { mechanized equip }\end{array}$ & 5.5124 & 22 & 9.0019 & 58 & 0.7490 & 0 \\
\hline Declining soil fertility & 2.7838 & 7 & 4.5848 & 19 & 1.0401 & 1 \\
\hline Low soil fertility status & 3.6063 & 10 & 2.8054 & 6 & 2.5036 & 5 \\
\hline $\begin{array}{l}\text { Lack of collateral to get } \\
\text { loan }\end{array}$ & 20.4097 & 233 & 7.9888 & 36 & 0.3128 & 0 \\
\hline Low genetic make-up & 8.1411 & 54 & -0.4999 & 0 & 0.1460 & 0 \\
\hline Poor access road & 23.6456 & 296 & 10.0965 & 54 & 1.4092 & 1 \\
\hline Pest/disease problem & -1.6987 & 2 & -14.0204 & 156 & -0.9788 & 1 \\
\hline $\begin{array}{l}\text { High incidence of } \\
\text { weeds }\end{array}$ & -6.4417 & 38 & 9.1861 & 77 & 2.6163 & 6 \\
\hline $\begin{array}{l}\text { High cost of NPK } \\
\text { fertilizer }\end{array}$ & -3.2971 & 9 & 11.1305 & 101 & 3.0775 & 8 \\
\hline $\begin{array}{l}\text { Absence of organic } \\
\text { fertilizer }\end{array}$ & 0.3661 & 0 & 0.0813 & 0 & 0.0750 & 0 \\
\hline $\begin{array}{l}\text { Negative impact of } \\
\text { agrochemicals. }\end{array}$ & -4.5945 & 36 & -5.1917 & 46 & 6.3548 & 69 \\
\hline $\begin{array}{l}\text { High cost of agro- } \\
\text { chemicals }\end{array}$ & -10.4615 & 215 & 3.0707 & 19 & -0.5147 & 1 \\
\hline $\begin{array}{l}\text { Challenges of } \\
\text { harvesting }\end{array}$ & -11.8020 & 135 & 3.1068 & 9 & 1.9659 & 4 \\
\hline $\begin{array}{l}\text { Poor storability of } \\
\text { tubers }\end{array}$ & -5.4825 & 24 & 4.1020 & 13 & 3.5706 & 10 \\
\hline Poor extension system & 2.3987 & 4 & 10.0673 & 76 & -6.6320 & 33 \\
\hline Unstable govt. policy & -7.4432 & 43 & 2.9943 & 7 & -2.1827 & 4 \\
\hline Soil erosion problem & -9.7327 & 70 & 3.3456 & 8 & -6.4054 & 30 \\
\hline $\begin{array}{l}\text { Low implementation of } \\
\text { agricultural policies }\end{array}$ & -13.3830 & 120 & 4.2880 & 12 & 2.9585 & 6 \\
\hline Low Market value & -7.1599 & 36 & 9.0483 & 58 & -0.0559 & 0 \\
\hline Soil erosion problem & -14.5327 & 165 & 2.2390 & 4 & 1.7167 & 2 \\
\hline Lack of market & -4.7873 & 17 & 9.0674 & 59 & 2.0465 & 3 \\
\hline
\end{tabular}


show any significant impact towards improving cassava value chain development in the area (Table 2).

The highly significant policy strategies are capable of identifying marketing opportunities and bringing these to the attention of stakeholders. The significant impact strategies are expected to meet up the needs of the industry before the public and decision-makers. Even if the stakeholders agree that there is a growth market for cassava, there is likely a need, for research and development, provision of infrastructure and investments, and changes in policies to utilize the new opportunities. Agricultural entrepreneurs are expected to seize the opportunity and develop new markets. This might be true in a perfect, risk free economy, but the entrepreneur has many alternatives, and may have other successful, ongoing ventures through diversification. In such cases the development of a new market, which relies on getting supplies from a large number of small cassava producers, may seem to be too risky. Also the entrepreneur may not have the skills or information on how to develop a new cassava product, such as convenience foods. It is because of this expectation that the free market will not always make greatest impact and use of the potential of cassava, nor necessarily use it in a way best suited to promote development, that the Strategic policy for Cassava was proposed.

The essence of the strategic policies on cassava expansion is to use a demand-driven approach to promote and develop cassava-based value chain with the assistance of a coalition of groups and individuals interested in developing the cassava industry. The policy strategies consists of identifying, in a systematic manner, the opportunities and constraints of cassava at each stage of the commodity development cycle. This can be done by groups and individuals interested in developing the cassava industry; producers, processors and consumers of cassava, as well as associated national, international and nongovernmental organizations. Concepts of business development and management as well as international economic cooperation are important tools in implementing the strategic policies. Scientific support is also essential to help overcome important problems within the production-processing-marketing continuum. Adaptive research is essential to ensure that existing and evolving knowledge is harnessed in an appropriate and useful fashion. The overall aim is to achieve demand-driven technical change and economic growth through expanded cassava productivity,

The strategic policies that will expand the frontiers of cassava - based farmers in the region would among others be based on the following;

- A practical, long-term vision with an overall goal of agricultural transformation using cassava as its commodity and product base. Agricultural transformation is the process of moving from subsistence agriculture to a modernized system based on improved techniques and information, specialization, market transactions, and greater profitability for producers and related industries;

- Established on past and present experience, knowledge and capability;

- Founded on careful and meaningful industry analysis of the production/processing/marketing system that is demand and market driven and includes both private and public sectors;

- Focus on production/processing/marketing as priority products where the priority products are farm and off-farm raw, intermediate, and consumer products that have the greatest potential to contribute to agricultural transformation and economic growth;

- Insist on adding value to cassava products to achieve greater returns to both producers and processors;

- Enhance the production of cassava and cassava based products;

- Acknowledge the critical importance of the processing of fresh roots to produce unique products with high market demand, including secondary products derived from primary products such as starch, chips and pellets; likewise, to recognize the central role of processing at the interface between supply side and demand-side interventions;

- Depend on a dynamic and innovative private/public partnerships between producers, processors, marketers, financiers, and government leaders as entire value chain actors;

- Realize the urgent need for actions relating to both demand for, and supply of, cassava products;

- Should be technologically driven

- Adopt knowledge and management intensive approaches; 
- Build institutional capacities in research and development support, processing, financing, and marketing

- Understand that there is no free ride to a productive, profitable cassava industry. To achieve this will require commitment of funds, development of human resources, and building of capacities, especially at national level, in research and development, management, processing excellence and marketing skills and ingenuity, including innovative and willing public support.

\section{DISCUSSION}

The present study had revealed that high presence of pest and diseases constituted constraints and limiting factors towards cassava production. This findings is in consonance with the assertions of Plucknett [22] who noted that practical soil and crop management can raise yield by more than $50 \%$, in addition to improvements in yield potential and pest and disease control could more than double yields. The combined efforts of alleviating pre-and postharvest constraints could increase economic yield by $133 \%$, or the equivalent of 41 Metric tonnes [22].

In most agrarian communities,, supporting and improving the status and performance of cassava as a food while expanding its potential commercial role should receive high priority, particularly with the rapid migration to urban centers and increasing income. This should involve public and private efforts, particularly various farmers groups who are major stakeholders, supported by infrastructure developments so as to reduce the current high production costs and make cassava more competitive with grains. Continuing research and

Table 2. Policy strategies to expand the frontiers of cassava value chain development in the study area

\begin{tabular}{|c|c|c|}
\hline Policy Strategies & Mean adoption Rate (\%) & Impact Significance (F-statistics) \\
\hline $\begin{array}{l}\text { Formation of cooperatives } \\
\text { society to enhance farmers' } \\
\text { access to finance }\end{array}$ & 78.65 & $4.26^{* \star}$ \\
\hline $\begin{array}{l}\text { Providing machineries for } \\
\text { production and processing }\end{array}$ & 54.24 & $3.82^{\star *}$ \\
\hline $\begin{array}{l}\text { Subsidizing the prices of } \\
\text { agricultural inputs }\end{array}$ & 60.23 & $3.65^{\star *}$ \\
\hline $\begin{array}{l}\text { Making planting material } \\
\text { available to farmer' at the right } \\
\text { time in the right quantity }\end{array}$ & 79.45 & $3.52^{\star *}$ \\
\hline Procurement of fertilizer & 54.42 & $3.21^{\star *}$ \\
\hline $\begin{array}{l}\text { Using of resistant and high } \\
\text { yielding varieties }\end{array}$ & 89.20 & $4.78^{* *}$ \\
\hline Creating credit facilities & 10.32 & $1.02 \mathrm{~ns}$ \\
\hline Making interest rate low & 12.87 & $0.83 \mathrm{~ns}$ \\
\hline $\begin{array}{l}\text { Establishment of starch based } \\
\text { industries in rural areas for } \\
\text { processing cassava }\end{array}$ & 34.19 & $1.91 \mathrm{~ns}$ \\
\hline $\begin{array}{l}\text { Planting improved varieties with } \\
\text { relatively low cyanide }\end{array}$ & 85.93 & $4.58^{\star *}$ \\
\hline $\begin{array}{l}\text { Creating market, roads and } \\
\text { social facilities like hospitals, } \\
\text { water and schools }\end{array}$ & 20.15 & $0.97 \mathrm{~ns}$ \\
\hline $\begin{array}{l}\text { Use of recommended spacing } \\
\text { and planting at the right time }\end{array}$ & 46.23 & $1.75 \mathrm{~ns}$ \\
\hline $\begin{array}{l}\text { Proper and regular weeding of } \\
\text { cassava farms }\end{array}$ & 38.96 & $1.99 \mathrm{~ns}$ \\
\hline $\begin{array}{l}\text { Regular visit by extension } \\
\text { agents for regular and proper } \\
\text { extension delivery system }\end{array}$ & 17.43 & $0.89 \mathrm{~ns}$ \\
\hline
\end{tabular}


development efforts are needed in soil fertility, tissue culture and rapid multiplication of planting material crop protection and integrated pest management for the continent where cassava has been greatly affected by pest and disease attack. Most of the constraints highlighted by National Population Commission [23] above were synonymous with the findings of the current study in which poor rural infrastructure in the study area such as poor road network, lack of electricity and processing equipment for cassava constituted higher loading constraints and limitations to expanded cassava productivity in the area $[24,25]$.

The present study shows the relative weakness of the expanded cassava problem to stern from low genetic make or poor germplasm used by farmers in the area for cultivation and production of cassava. This has not only lowered the yield of cassava but also reduced the biological as well as market value. This is in line with the reports of $[26,27]$ who opined that use of unimproved stem cuttings has resulted to a significant yield of up to $72.3 \%$. This according to the reports showed high susceptibility to the wild cassava mosaic virus and other pest and diseases which off course hindered their performance in the field. As a strategic policy to overcome this barrier, the global agricultural research system now provides an additive or multiplicative effect to national research efforts. The adoption of modern agricultural research system would provide a source of new genetic materials, new methodologies, training in advanced research techniques, and provides a bridge to technical advice to farmers in the study area [28].

The present study also revealed that the absence of technical knowhow on the part of the resource poor farmers. Research and development are needed in the areas of genetic improvement and product development and processing. This policy strategy needs to be supplemented by the development of organizations, institutions and policies that facilitate the development of cassava industries. The Global Cassava Strategy has shown that genetic improvement of cassava germplasm should be synonymous with the use of cassava. Thus the best cassava is no longer the highest yielding cassava, or the cassava with the greatest resistance, unless it is an improved variety developed for use in the production of a specific product. To this end genetic resources of cassava comprise a major element of the global cassava development strategy and deserve international support and cooperation in their conservation, study and use. Both the Centro Internacional de Agricultura Tropical (CIAT) in Colombia, and the International Institute of Tropical Agriculture (IITA) in Nigeria hold large collections of cassava germplasm. Brazil's National Center for Genetic Resources and Biotechnology holds both cassava and wild Manihot species, while its National Cassava and Fruit Research Center (CNPMF) in Bahia holds the world's largest national collection of cassava germplasm $[29,30]$.

Many of the major pests and diseases of cassava are endemic in Africa, making this country a key location in providing 'hotspot' environments to find test genotypes for their resistance or susceptibility to those pest and disease problems. Cassava breeding and development should follow even more closely a tailoring approach to suit final uses. More investment in research is needed for the evaluation for specific traits, for biotechnology research to help speed development of new varieties, for the improvement of integrated pest management practices, for the identification of needed genes and for the acceleration of genetic enhancement and plant breeding [31]. Cassava bound for fresh food is likely to contain less hydrocyanic glucosides than varieties slated for processing. Also, varieties destined for processing for starch should have high levels of starch and have peel and root forms suitable for ease of processing [31]. When this is achieved it will help to create a favourable disposition for increased cassava production in the study area and the country at large.

The current study reveals that most of the strategic policies adopted in the study area showed variable levels of significant positive impact on the expanded cassava production initiative. This findings is in tandem with the positions of Hershey, et al. [19,32] who posited that the demand driven approach inevitable leads to needs for research and development related to the production and processing of cassava. Lowering costs, increasing efficiency and improving quality become increasingly important targets for research and development. These targets also suggest the need for adaptation and validation of research results for the various stages of the cassava supply chain. Some possible policy strategies aimed at expanding the frontiers of cassava production in the area include the following: Improved production systems to produce more per unit of land; reduce 
costs of production and increase product value, while keeping cost of production the same or lower $[9,32]$.

Hence, adequate policy strategies should include processing research to develop new products; adapt and develop methods and techniques of processing; utilize native and modified cassava starches; develop improved and advanced methods to modify cassava products and to improve small-scale processing [13,32]. Environmental research to reduce soil erosion, research on motivation and practices; reduction in pollution, especially in the production/processing for industry and to prevent destruction of ecosystems, forests, shifting cultivation are all aimed at expanding the frontiers of cassava production in the study area [33]. Institutional research, development and policy to reduce barriers to the development of cassava products and markets; promote public/private sector partnerships; provide information support for the cassava development effort; provide necessary infrastructure and provide training and extension support to the cassava development effort will go a long way to expand the frontiers of cassava production in the region. Moreso, crop management research should focus on development and extension to improve agronomic practices, develop improved pest management practices and also the development appropriate mechanization for the various stages of the cassava value chain development $[34,35,36]$.

\section{CONCLUSION}

The study ascertained the policy strategies that should be adopted to enhance increased production of cassava and associated products. It present study identified possible constraints to expanding the frontiers of cassava value chain and evaluated positive strategic policies towards improving cassava production and processing in Cross River State, Nigeria. The result showed the identified constraints to cassava production and processing to include agronomic factor as such as difficulties of harvesting during dry season, lack of adequate technical knowledge of modern processing technique and poor access road for transportation of farm procedure and financial factor including lack of finance, difficulties in obtaining credit facility, lack of collateral required to secure loan, high cost of inorganic fertilizer, high cost of agro chemicals, lack of modern processing equipment and high cost of processing, poor technical knowhow, poor resource management weed problem, high incidence of pest and diseases, unavailability of agro-chemicals and other insecticides, soil erosion problem and soil fertility problem, technical/institutional problems including scarcity of planting materials, high cost of improved varieties, limited processing option, instability in government policy,. Policy strategies such as expanding production systems, processing research, environmental research, institutional research, development and policy development as well as crop improvement research are barrier breakers needed to expand the frontiers of cassava production. Most of the strategic policies evaluated revealed significant impact on cassava productivity while a few others showed nonsignificant impact on cassava value chain development.

\section{RECOMMENDATION}

Hence, the continued strong agitation and the increasing demand for cassava food productivity is a pointer to the important role cassava plays in human and animal nutrition. Thus, farmers should be encouraged and assisted by agricultural extension agents and local leaders in the rural areas to join or set up farmer groups or organization. This will enable the farmers / processors to benefits and have access to funds on time and farm inputs required for cassava production and processing. Government policy on cassava should encourage the establishment of cassava-based cottage industries in rural areas. This will go a long way in reducing youth unemployment, food insecurity in the study area and the country at large.

\section{COMPETING INTERESTS}

Authors have declared that no competing interests exist.

\section{REFERENCES}

1. Nweke Felix I, Ugwu BO, Dixon AGO. Spread and performance of improved cassava varieties in Nigeria. COSCA. Collaborative Study of Cassava in Africa, IITA, Ibadan, Nigeria. 1996;15.

2. El Bilali H, Callenius C, Strassner C, Probst L. Food and nutrition security and sustainability transitions in food systems. Food and Energy Security. 2019;8(2): e00154.

3. Hershey CG, Henry Rupert B, Kazuo K, Reinhardt H, Carlos I. Cassava in Asia; 2007. 
4. Chukwuone NA, Agwu AE, Ozor N. Constraints and strategies towards effective cost-sharing of agricultural technology delivery in Nigeria: Perception of farmers and agricultural extension personnel. Journal of International Agricultural and Extension Education. 2006;13(1):29-40.

5. Plucknett DL, Phillips TP, Kagbo RB. A global development strategy for cassava: transforming a traditional tropical root crop. Draft Report Prepared for the International Fund for Agricultural Development (work in progress); 1998.

6. Rockström J, Steffen W, Noone K, Persson Å, Chapin FS, Lambin E, Foley J. Planetary boundaries: Exploring the safe operating space for humanity. Ecology and Society. 2009;14(2).

Available:https://doi.org/10.5751/ES03180-140232

7. Steffen W, Richardson K, Rockstrom J, Cornell SE, Fetzer I, Bennett EM, Sorlin D. Planetary boundaries: Guiding human development on a changing planet. Science. 2015;347(6223):1259855. Available:https://doi.org/10.1126/science.1 259855

8. FAO. Draft working notes on selected chapters of The World Cassava Economy: Recent trends and medium-term outlook. Global Cassava Development Strategy: Progress Review Workshop. Rome: International Fund for Agricultural Development; 1997.

9. Waha K, Van Wijk MT, Fritz S, See L, Thornton PK, Wichern J, Herrero M. Agricultural diversification as an important strategy for achieving food security in Africa. Global Change Biology. 2018;24(8):3390-3400.

10. Tyczewska A, Woźniak E, Gracz J, Kuczyński J, Twardowski T. Towards food security: current state and future prospects of agrobiotechnology. Trends in Biotechnology. 2018;36(12):1219-1229.

11. Onodu B, Culas R. The role of Cassava production in improving food security in the delta state of Nigeria. In food security: Threat factors, policies and challenges Nova Science Publishers. 2017;1-34.

12. FAO. FAOSTAT Database Collections. Web Page; 1999.

Available:http://apps.fao.org/cgi-bin/nphdb.pl?subset=agriculture

13. FAO. Medium-term prospects for agricultural commodities: Agricultural commodity projections to 2005. Committee on Commodity Problems: Sixty-second Session. Rome: FAO; 1999.

14. Nneoyi IO, Henry MN, Walter AM, Ebingha EE. Group dynamics and technology use among female cassava farmers in Akpabuyo Local Government Area, Cross River State, Nigeria. Agricultural Journal. 2008;3(4):292-298.

15. Federal Republic of Nigeria. National Report on International Conference On Agrarian Reform and Rural Development held at Porto Alegre. 2006;1-22.

16. Cassava. Assembled by DTP Studies Inc. and funded by IDRC, Ottawa, and IFAD, Rome; 2009.

17. Hershey Clair, Guy Henry. Cassava in Latin America \& Asia: A regional Review (Summary). Global Cassava Development Strategy: Progress Review Workshop. Rome: International Fund for Agricultural Development; 1997.

18. Porter G. Access to market opportunities in Ghana's off-road communities. Report to the UK Department for International Development. 1999;50.

19. Hershey C, Henry G, Rupert B, Carlos I. Cassava in Latin America and the Caribbean; 2017.

20. Hershey $\mathrm{CH}$. Report of the Asia Regional Consultation on the Global Cassava Development Strategy. Cali, Colombia: CIAT; 2009.

21. IFAD, FAO. A review of cassava in Africa with country case studies on Nigeria, Ghana, the United Republic of Tanzania, Uganda and Benin; 2005.

22. Plucknett D. Cassava Research in China, Washington DC; 2005.

23. National Population Commission. Nigeria Population Figure. National Population Commission, Abuja. Proceedings of the Validation Forum on the Global Cassava Development Strategy. FAO, Rome. 2006; 2.

24. Porter G. Marketplaces in Nigeria: patterns of continuity and change. The Nigerian Field. 2004;65(1-2):92-100.

25. RIM. Nigerian livestock resources. 2012;1. Executive Summary and Atlas. Resource Inventory and Management Limited, Jersey, U.K. RTEP. Report of the mission on identification of domestic markets for cassava products Agro-industrial Development Unit, Federal Department of Agriculture, Abuja; 2003. 
26. Phillips T. Cassava Utilization and Potential Markets. IDRC-20e ed. Ottawa, Canada: International Development Research Centre; 2014.

27. Ratanawaraha C, Senanarong N, Suriyaphan P. Status of Cassava in Thailand: Implications for Future Research and Development. Global Cassava Development Strategy: Progress Review Workshop. Rome: International Fund for Agricultural Development; 2017.

28. Sanni LO, Charles A, Kuye A. Moisture sorption isotherms of fufu and tapioca, Journal of Food Engineering. 2012;34:203212.

29. Sanni LO. Cassava utilisation and regulatory framework in Nigeria. UNIDO. Sanni LO. 2002. Trends in the drying of cassava in Africa. 12th Symposium of ISTRC-Tsukuba Japan, Nakatani and Komaki Editors. 2005;113-120.

30. Westby A. Global cassava development strategy: Brainstorming session with African researchers. 7th Triennial Symposium-International Society of Tropical Root Crops -Africa Branch; 2018.

31. Price Water House Coopers. The Nigeria Investors Roadmapand Enabling Environment Strategy Final Report,
Prepared for the Government of the Federal Republic of Nigeria, USAID Nigeria. 2012;254.

32. Spencer Dunstan A. Scholar Cassava in Africa: Past, Present and Future, Freetown, Sierra Leone; 1997.

33. Tonukari NJ. Cassava and the future of starch. Electronic Journal of Biotechnology. 2004;7(1):15.

34. Ugwu CC. Gender roles in cassava production and processing in Enugu North Agricultural Zone of Enugu State, Nigeria. B. Agric Thesis, Department of Agricultural Extension, University of Nigeria, Nsukka; 2008.

35. Working Group on International Agricultural Research. The Crucial Role of International Agricultural Research: Improving Global Food Production, benefiting US. Agriculture, enhancing the economies of developing countries and stimulating U. S. Trade, National Center for Food and Agricultural policy, Washington, DC; 2017.

36. Titapiwatanakun Boonjit. Report of Strategy Agricultural Commodity Project: cassava, Agribusiness Research Unit, Department of Agricultural and Resource Economics, Faculty of Economics, Kasetsart University, Bangkok; 2017.

(0) 2019 Agbachom et al.; This is an Open Access article distributed under the terms of the Creative Commons Attribution License (http://creativecommons.org/licenses/by/4.0), which permits unrestricted use, distribution, and reproduction in any medium, provided the original work is properly cited.

Peer-review history:

The peer review history for this paper can be accessed here: https://sdiarticle4.com/review-history/52780 